\title{
Behaviour analysis of load-bearing aluminium members
}

\author{
A. Hirkovskis; \\ D. Serdjuks; \\ V. Goremikins; \\ L. Pakrastins, \\ Riga Technical University; \\ N.I. Vatin,
}

Peter the Great St. Petersburg Polytechnic University

\begin{abstract}
Aluminium is one of the traditional structural materials. Structures made of aluminium alloys are widely used in the civil engineering for erection of new civil and industrial buildings and reconstruction of the existing ones. Increased corrosion resistance, stability of mechanical properties at negative temperatures, lightness and increased durability are the main advantages of aluminium alloys as the structural materials.

Design approaches described in EN 1999 and SNiP 2.03.06-85 for the aluminium elements, subjected to bending and combined bending and compression, were compared analytically and on the base of laboratorial experiment for the simple beams with the rectangular hollow cross-sections with the heights 65,85 and $105 \mathrm{~mm}$ loaded by the two concentrated forces. It was stated, that the difference between the results is within the limits from $5.82 \%$ to $12.92 \%$. The differences between the experimental and numerical results are within the limits from $3 \%$ to $7 \%$ for both methods. Rational values of height of the transversal arch, amount of the arch's segments and a spacing of transversal arches of load-bearing framework for spacious exterior structure were determined by the response surface method for the structure with the span equal to $9 \mathrm{~m}$.

It was shown, that the rational height of the transversal arch and amount of the arch's segments changes from 1.76 to $1.94 \mathrm{~m}$ and from 10.70 to $11.97 \mathrm{~m}$, correspondingly. The corresponding minimum materials consumptions were equal to $6.16,5.38$ and $5.54 \mathrm{~kg} / \mathrm{m}^{2}$.
\end{abstract}

Key words: rational parameters; spacious aluminum structure; response surface method

\section{Introduction}

Aluminium is a structural material widely used in civil engineering. The main application fields of aluminium alloys are the erection of new civil and industrial buildings and the reconstruction of existing ones. Structures made of aluminium alloys have the following advantages: increased corrosion resistance, stability of mechanical properties at negative temperatures, lightness and increased durability. Aluminium alloys are used for load-bearing structures of light frameworks, for structures of facades, molds of columns, floors and load-bearing walls, structures of stairs, doors, partitions, balconies and other structures (Fig. 1).

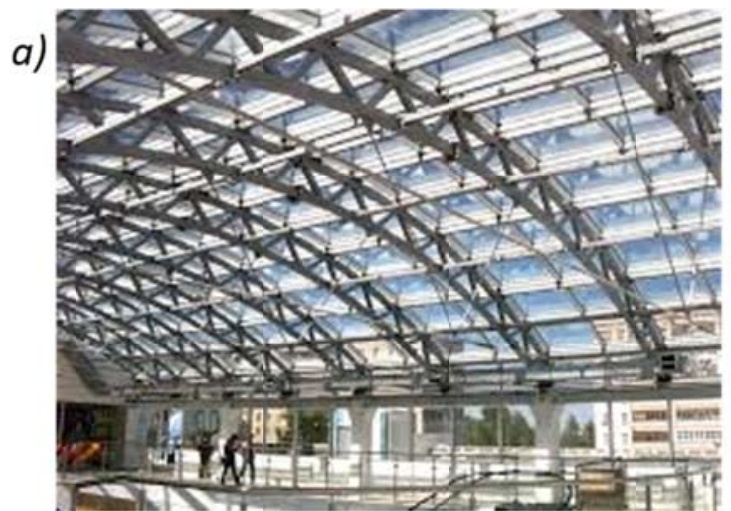

b)

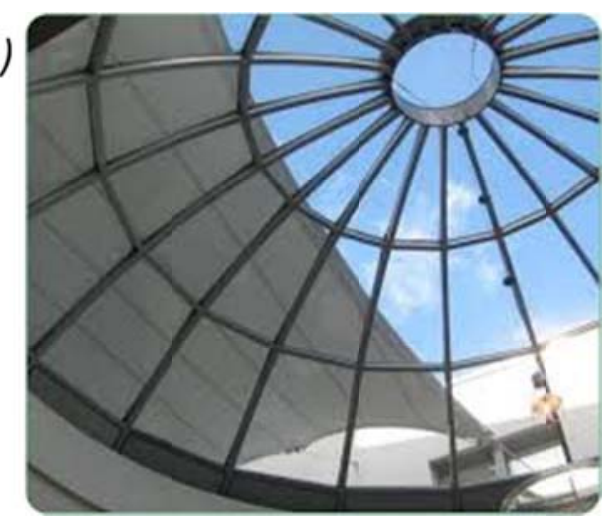

Figure 1. Examples of structures from aluminium alloys:

a) light framework from aluminium alloys; b) spacious framework for exterior structures

Hirkovskis A., Serdjuks D., Goremikins V., Pakrastins L., Vatin N.I. Behaviour analysis of load-bearing aluminium members 
But the most material consuming field of application of structural aluminium elements are flat and spacious frameworks for exterior structures (Fig. 1b). These structures combine load-bearing and decorative functions. Choice of rational geometrical parameters for these structures is a very important aspect of a designing process because it enables to obtain the structural solution, which is characterized both by the rational using of structural materials and good appearance. In this connection, the framework of exterior structure of a residential building in Oslo (Fig. 2) is considered to be a prototype of the object of investigation.

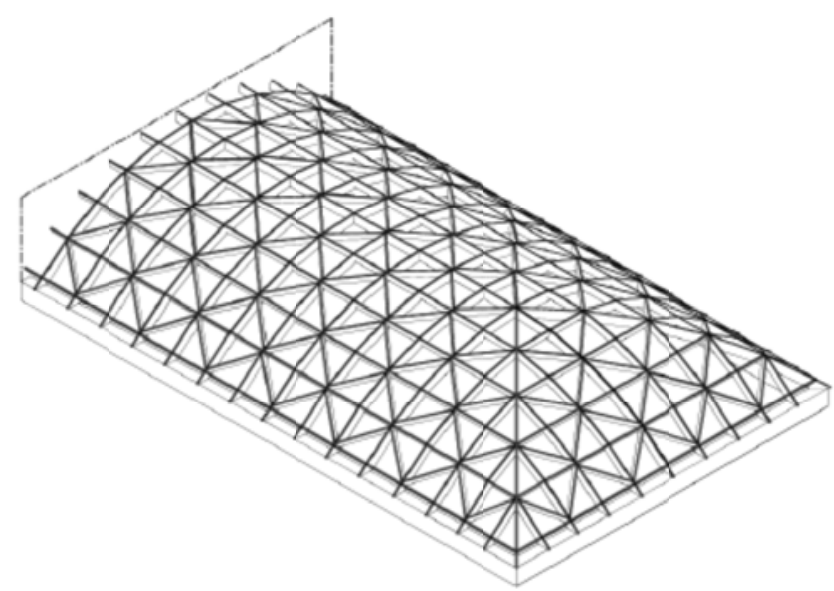

Figure 2. Object of investigation - spacious framework for exterior structure of residential building in Oslo

So, it can be concluded, that structural units made of aluminium alloys are mostly subjected to bending and combined bending and compression. The EN 1999 and SNiP 2.03.06-85 are structural codes, which are used for the designing of aluminium structures in Latvia and neighbouring states. Comparison of the approaches described in both codes causes a certain interest because the structures designed by both codes can be available in the Latvian structural market.

Therefore, the aim of this paper is to evaluate the rational geometrical parameters from the point of view of materials consumption of load-bearing spacious external structure in Oslo, made of the aluminium alloys. Corresponding methods for design or calculation of main load-bearing elements of considered framework must be suggested and checked by the experiment. Approaches for the design of loadbearing aluminium elements, described in EN 1999 and SNiP 2.03.06-85 must be compared for this purpose.

\section{Design methods description for structural aluminium elements}

\subsection{Elements subjected to combined bending and compression}

Let us start with the consideration of design methods for structural aluminium elements, which are subjected to combined bending and compression. Approaches for the designing of load-bearing aluminium elements, which are described in the sources [1,2] will be considered, as it was mentioned above. Let us consider the main peculiarities of designing of structural aluminium elements subjected to combined bending and compression [1]. The determinant check is a check of stability, which can be conducted by the equations (1) and (2) or (3) dependently on the parameters of the elements crosssections. For open cross-sections, such as T and double-T profiles, U-shape and symmetric about both major axes cross-sections stability of the element subjected to combined bending and compression must be checked by the equations (1) and (2). Equation (1) is used for check of elements stability about the major axis, where the element has maximum rigidity in bending. Equation (2) is used for check of elements stability about another major axis, [1].

Hirkovskis A., Serdjuks D., Goremikins V., Pakrastins L., Vatin N.I. Behaviour analysis of load-bearing aluminium members 


$$
\begin{gathered}
\left(\frac{N_{E d}}{\chi_{y} \cdot \omega_{x} \cdot N_{R d}}\right)^{\zeta_{y c}}+\frac{M_{y, E d}}{\omega_{0} \cdot M_{y, R d}} \leq 1, \\
\left(\frac{N_{E d}}{\chi_{z} \cdot \omega_{x} \cdot N_{R d}}\right)^{\eta_{c}}+\left(\frac{M_{z, E d}}{\omega_{0} \cdot M_{z, R d}}\right)^{\zeta_{z c}} \leq 1,
\end{gathered}
$$

where $N_{E d}, M_{y, E d}, M_{z, E d}$ are the design values of axial compression force and bending moments which act about the both major axes $y$ and $z ; N_{R d}, M_{y, R d}, M_{z R d}$ are the design resistances of the elements crosssections in compression and bending about the both major axes; $X_{y}, X_{z}$ are reduction factors about the both major axes; $\zeta_{y c}, \zeta_{z c}, \eta_{c}$ are the factors which depend on the slenderness of the element about the both major axes and geometrical parameters of elements cross-section. The factors $\zeta_{y c}, \zeta_{z c}, \eta_{c}$ are bigger or equal to 0,$8 ; y$ - major horizontal axis of cross-section; $z$ - major vertical axis of crosssection.

The value of coefficient $\omega_{0}$ can be taken equal to 1 . For closed cross-sections such as SHS and RHS stability of the element subjected to combined bending and compression must be checked by the equation (3).

$$
\left(\frac{N_{E d}}{\chi_{\min } \cdot \omega_{x} \cdot N_{R d}}\right)^{\psi_{c}}+\frac{1}{\omega_{0}}\left[\left(\frac{M_{y, E d}}{M_{y, R d}}\right)^{1.7}+\left(\frac{M_{z, E d}}{M_{z, R d}}\right)^{1.7}\right]^{0.6} \leq 1,
$$

where factor $\psi_{c}$ depends on the slenderness of considered element. The factor $\psi_{c}$ is bigger or equal to 0,8 .

Let us consider approach to design of the elements subjected to combined bending and compression in accordance with the source [2]. The determinant check is a check of stability, which can be conducted by the equation (4).

$$
\frac{N}{\varphi_{e} \cdot A}+\frac{M_{x}}{I_{x n}} \cdot y+\frac{M_{y}}{I_{y n}} \cdot x \leq R \cdot \gamma_{c},
$$

where $N, M_{x}, M_{y}$, are the design values of axial compression force and bending moments about both major axes; $x, y$-distances from the corresponding major axes to the considered points; $A$ - crosssectional area ; $I_{x n}$ and $I_{y n}$ - cross-sections moments of inertia about major axes $x$ and $y$, correspondingly; $\varphi_{e}-$ reduction factor; $\mathrm{R}$ - design resistance of material; $\gamma_{c}$ - safety factor.

The reduction factor $\varphi_{e}$ is a function of the elements slenderness and reduced relative eccentricity, which must be determined in accordance with recommendations of [2] dependently on the relation of the bending moment and axial force and shape of the elements cross-section.

\subsection{Elements subjected to bending}

Let us consider design methods for structural aluminium elements, which are subjected to bending. Approaches for the designing of load-bearing aluminium elements described in [1, 2] will be considered, as it was mentioned above. Let us consider the main peculiarities of designing of structural aluminium elements subjected to bending by [2]. Checks of the elements strength at the action of bending moment and shear forces can be done by the equations (5) and (6), respectively.

$$
\begin{aligned}
& \frac{M}{W_{n \cdot \min }} \leq R \cdot \gamma_{c}, \\
& \frac{Q \cdot S}{I \cdot b} \leq R_{s} \cdot \gamma_{c},
\end{aligned}
$$

Hirkovskis A., Serdjuks D., Goremikins V., Pakrastins L., Vatin N.I. Behaviour analysis of load-bearing aluminium members 
where $M$ and $Q$ are design values of bending moment and shear force; $R$ - design strength of aluminium alloy in bending, compression and tension; $R_{s}$ - design strength of aluminium alloy in shear; $I$ - moment of inertia of cross-section; $S$ - static moment of cross-section; $b$ - width of cross-section in the zone where shear stresses are determined; $W_{n, \min }$ - minimum modulus of section. bending.

Additional condition (7) must be satisfied for the webs of the structural elements subjected to

$$
\sqrt{\sigma_{x}^{2}-\sigma_{x} \cdot \sigma_{y}+\sigma_{y}^{2}+3 \tau_{x y}} \leq R \cdot \gamma_{c},
$$

where $\sigma_{x}, \sigma_{y}$ are the normal stresses, which act parallel to the axes $x$ and $y ; T_{x y}$ - shear stresses in the considered cross-section.

Let us consider the approach to design of the elements subjected to bending in accordance with the [1]. Checks of the elements strength at the action of bending moment can be done by the equation (8).

$$
\frac{M_{E d}}{M_{R d}} \leq 1,
$$

where $M_{R d}$ - resistance of cross-section in bending; $M_{E d}-$ design value of bending moment acting in the considered member.

Resistance of the elements cross-section in bending must be determined by the formula (9) taking into account influence of the cross-section's shape by the coefficient $\alpha_{y}$ :

$$
M_{y \cdot R d}=\frac{\alpha_{y} \cdot W_{y} \cdot f_{0}}{\gamma_{M 1}},
$$

where $W_{y}$ is elastic modulus of section about $y$ axis; $f_{0}$ is design resistance of the considered aluminium alloy in bending; $\gamma_{M 1}$ is partial safety factor.

Determinations of the cross-section shape coefficient $\alpha_{y}$ and partial safety factor $\gamma_{M 1}$ are described in details in [1]. Checks of the elements strength at the action of shear force can be done by the equation (10).

$$
\frac{V_{E d}}{V_{R d}} \leq 1,
$$

where $V_{R d}$ - resistance of cross-section in shear; $V_{E d}$ - design value of shear force acting in the considered member.

Resistance of the elements cross-section in shear must be determined by the equation (11):

$$
V_{R d}=A_{v} \cdot \frac{f_{0}}{\sqrt{3} \cdot \gamma_{M 1}},
$$

where $A_{v}$ - cross-sectional area, which works in shear.

Area of cross-section working in shear is determined as a product of gross area of the elements cross-section at the coefficient $\eta_{v}$, which can be equal to 0,6 or 0,8 dependently on the elements type [1].

Comparison of both the methods enables to conclude that both the approaches are comparable. The approach, described in the source [2], is characterized by the decreased workability, but the approach described in the source [1], is characterized by the increased precision. Materials work dependently on the geometrical parameters of cross-section is taken into account by its classification. Influence of the cross-sectional shape on the elements behaviour is evaluated by the cross-sectional shape coefficient $\alpha_{y}$, which takes into account influence of the welding as well. Both methods will be treated by a laboratory experiment in the next chapter of the paper.

Hirkovskis A., Serdjuks D., Goremikins V., Pakrastins L., Vatin N.I. Behaviour analysis of load-bearing aluminium members 


\section{Experimental verification of design methods for structural aluminium elements}

The profiles made of the aluminium alloy EN-AW-6060 T66 [3] produced by the Schuco company with the rectangular hollow cross-sections with the heights equal to $65 \mathrm{~mm}, 85 \mathrm{~mm}$ and $105 \mathrm{~mm}$ were used for experimental verification of design approaches described in [1, 2]. The beam subjected to four-point bending was considered as a scheme for the experiment (Fig. 3).
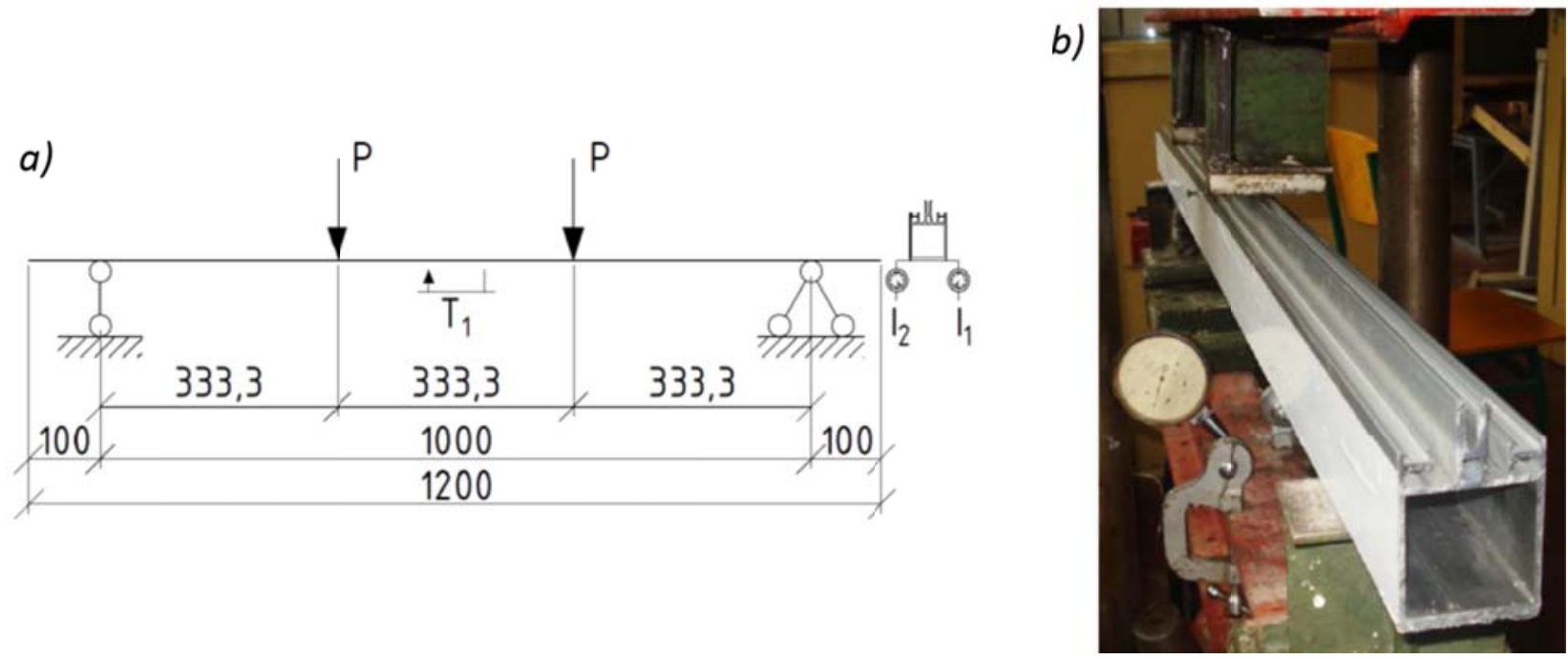

Figure 3. Scheme of the laboratorial experiment:

a) scheme of laboratorial experiment; b) profile placement in the hydraulic jack

Three elements with the lengths equal to $1200 \mathrm{~mm}$ each were simply supported with the spans equal to $1000 \mathrm{~mm}$ and loaded by two concentrated forces, which divided the span at three equal parts (Fig. 3). The value of total vertical load changed within the limits from $2 \mathrm{kN}$ to $12 \mathrm{kN}$ with the step equal to $2 \mathrm{kN}$. The vertical load was applied by the hydraulic jack with capacity of 3 tons. Two mechanical deflectometers I-1 and I-2 and one strain gauge T-1 were placed in the middle of the span. The specimens were also analyzed by the approaches explained in [1, 2]. Normal stresses as a function of the vertical load obtained for the rectangular hollow cross-sections with the heights equal to $85 \mathrm{~mm}$ and $105 \mathrm{~mm}$ are shown in Figure 4.

a)

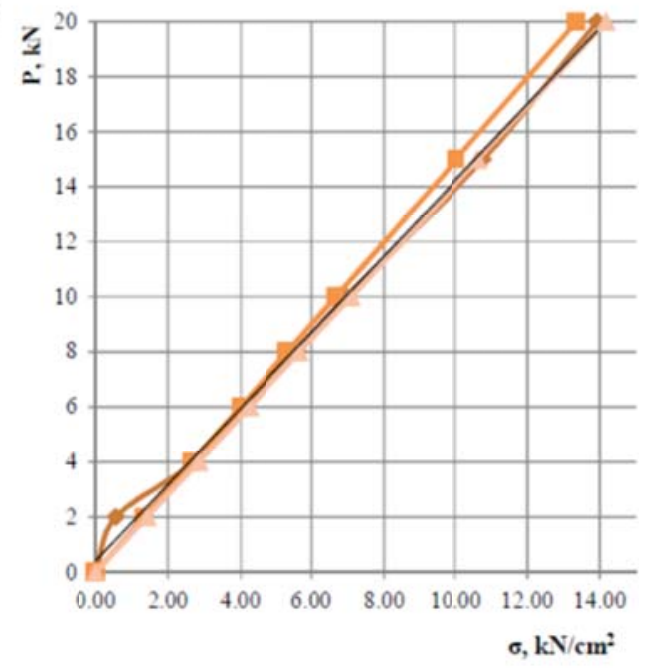

b) $\geq$

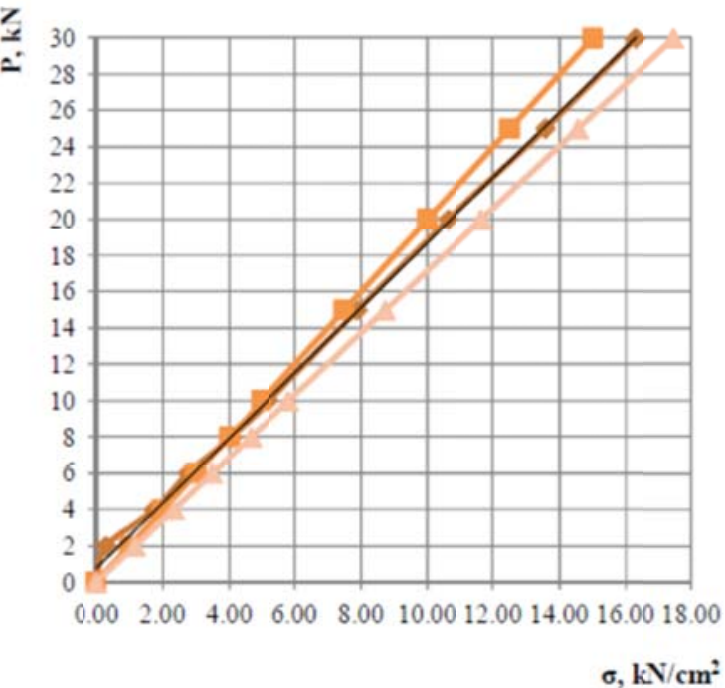

Figure 4. Normal stresses as a function of the vertical load obtained for the rectangular hollow cross-sections: a) cross-section with the height of $85 \mathrm{~mm}$;

b) cross-sections with the height of $105 \mathrm{~mm}$

Hirkovskis A., Serdjuks D., Goremikins V., Pakrastins L., Vatin N.I. Behaviour analysis of load-bearing aluminium members 
The dependence for the profile with the height of $65 \mathrm{~mm}$ has the similar character. Normal stresses as a function of the strains obtained for the rectangular hollow cross-sections with the heights equal to $85 \mathrm{~mm}$ and $105 \mathrm{~mm}$ are shown in Figure 5.
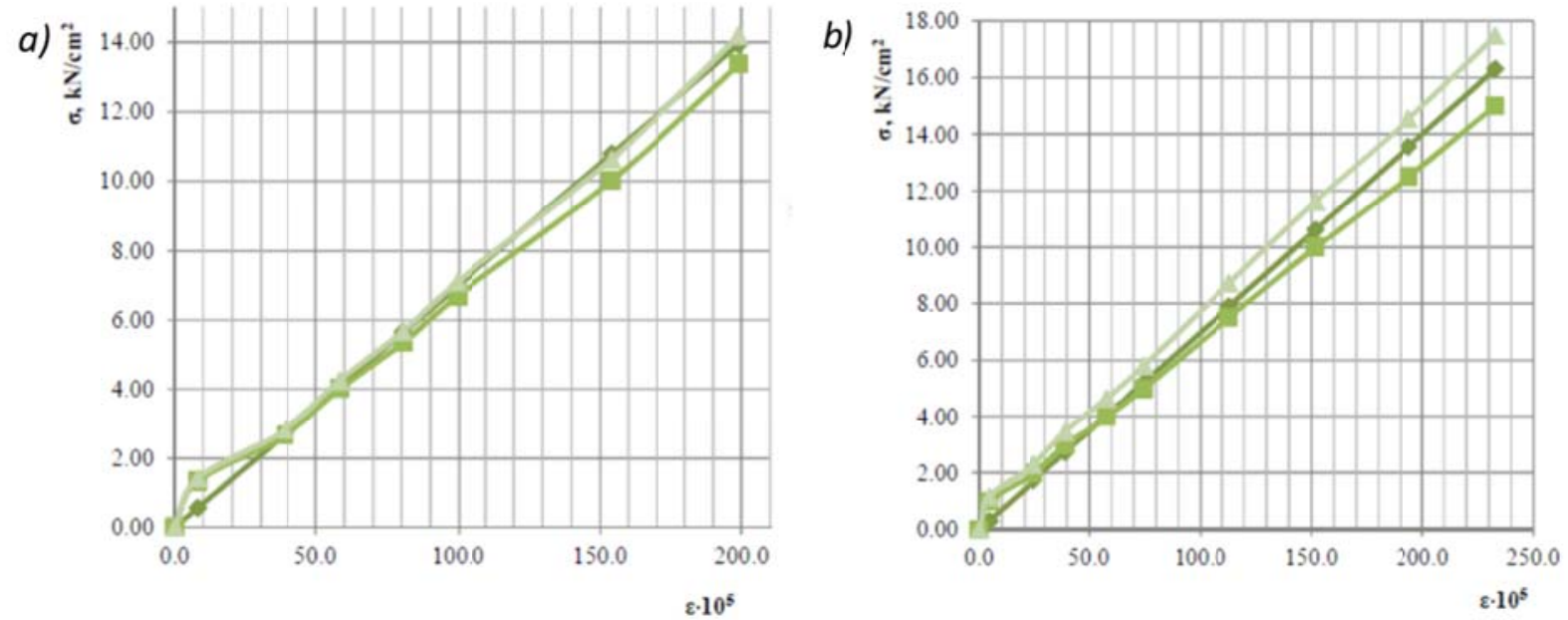

Figure 5. Normal stresses as a function of the strains obtained for the rectangular hollow cross-sections a) cross-section with the height of $85 \mathrm{~mm}$;

b) cross-sections with the height of $105 \mathrm{~mm}$

Maximum vertical displacements as a function of the vertical load obtained for the rectangular hollow cross-sections with the heights equal to $85 \mathrm{~mm}$ and $105 \mathrm{~mm}$ are shown in Figure 6.

a)

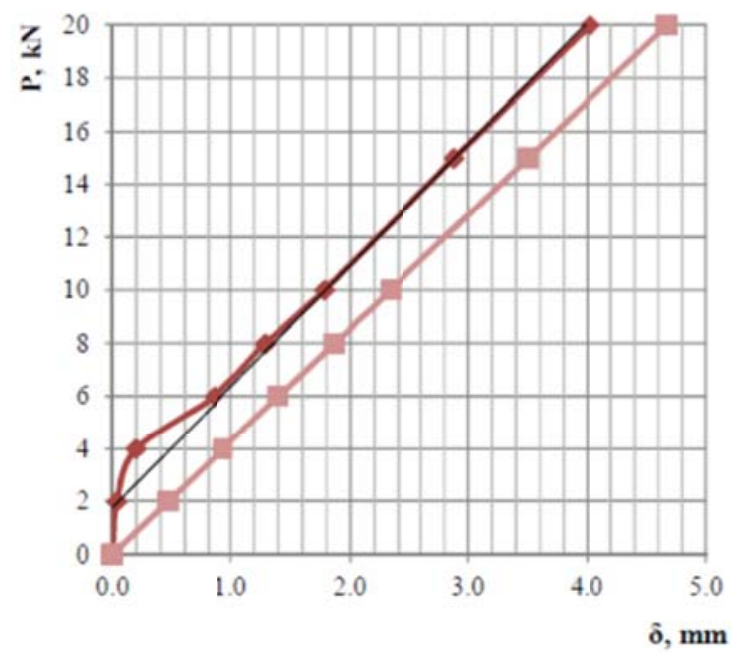

b)

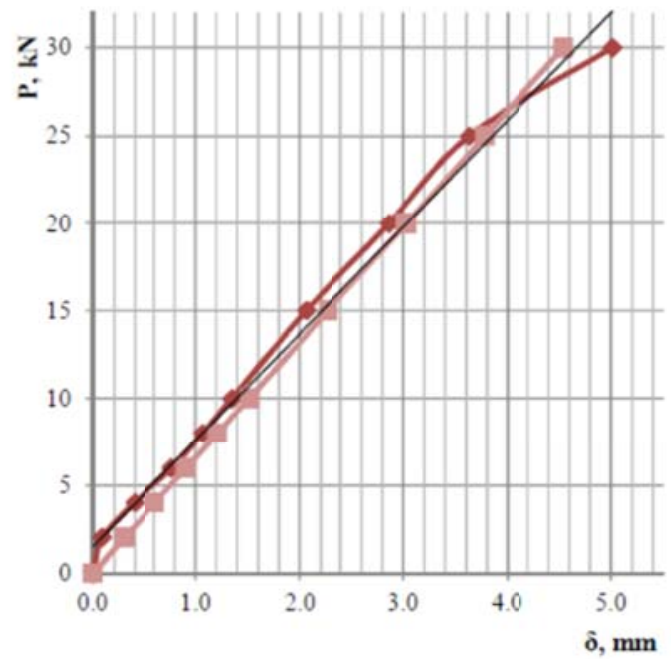

Figure 6. Maximum vertical displacement as a function of the vertical load obtained for the rectangular hollow cross-sections with the heights equal to $85 \mathrm{~mm}$ and $105 \mathrm{~mm}$ : a) cross-section with the height of $85 \mathrm{~mm}$; b) cross-sections with the height of $105 \mathrm{~mm}$

The comparison of the results obtained analytically by the approaches described in [1, 2] and by experiment enables us to conclude, that the difference is insufficient for both considered approaches and is within the limits from $3 \%$ to $7 \%$ for both approaches. The difference between the results obtained by the approaches described in [1, 2] changes within the limits from $5.82 \%$ to $12.92 \%$ for the considered profiles with the heights $65 \mathrm{~mm}, 85 \mathrm{~mm}$ and $105 \mathrm{~mm}$. So it can be concluded, that both methods enable to predict behaviour of the considered element with available precision, but the approach described in [1] allows to take into account a number of additional parameters in comparison with the approach considered in [2]. So, approach described in [1] will be used next in frames of this current investigation.

Hirkovskis A., Serdjuks D., Goremikins V., Pakrastins L., Vatin N.I. Behaviour analysis of load-bearing aluminium members 


\section{Evaluation of rational geometrical parameters of load-bearing framework of spacious exterior structure}

\subsection{Approach to the solution of the problem}

The framework of exterior structure of a residential building in Oslo (Fig. 2) is considered to be a prototype of the object of investigation. The considered object of investigation is shown on Figure 7.

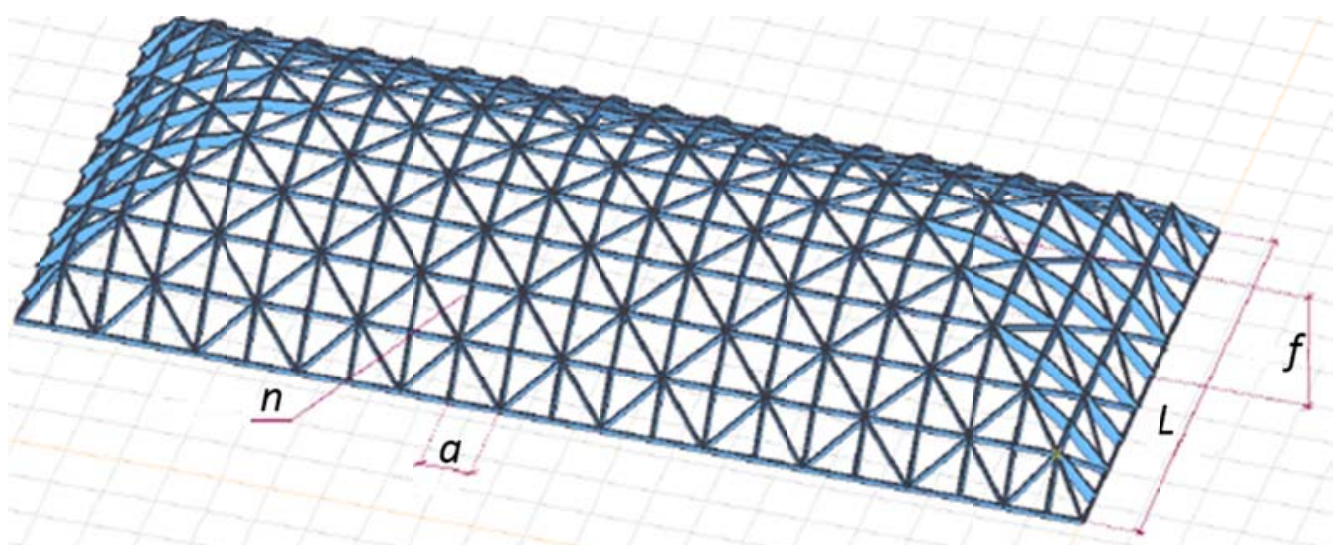

Figure 7. Load-bearing framework of spacious exterior structure with the main geometrical parameters: $\boldsymbol{f}$ - height of the transversal arch; $\boldsymbol{n}$ - amount of the arch's segments; a - spacing of transversal arches; $L$ - span

The dependence of the main geometrical parameters of the load-bearing framework of spacious exterior structure on the materials consumption were determined as the second order polynomial equations for three grades of aluminium alloys [4-6]. The considered grades are EN-AW-5454, EN-AW-6060 T66 and EN-AW-7020 T6 [3]. The main geometrical parameters of considered load-bearing framework of spacious exterior structure are height of the transversal arch $(f)$, amount of the arch's segments $(n)$ and a spacing of transversal arches (a) (Fig. 8).

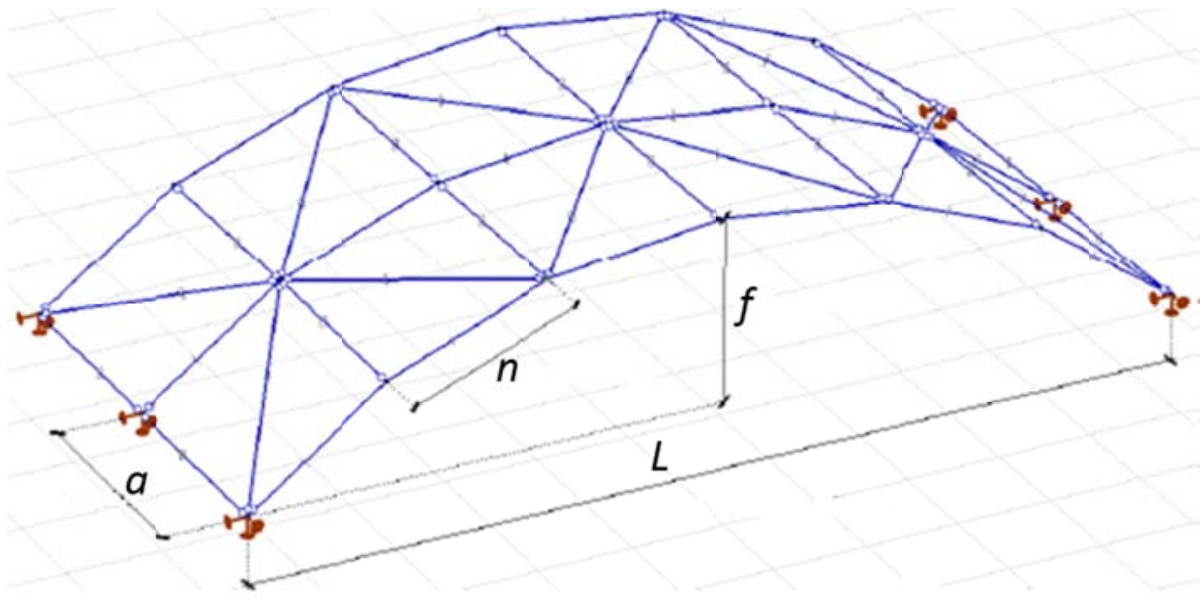

Figure 8. The main geometrical parameters of considered load-bearing framework of spacious exterior structure

The response surface method was used for evaluation of rational values of height of the transversal arch, amount of the arch's segments and spacing of transversal arches [7-9]. Materials consumption of the framework, related to the covered area, was considered as a criterion of rationality [10-12]. The mentioned geometrical parameters of the load-bearing framework were considered as the variables [13-17]. 


\subsection{Numerical results}

The span of the considered framework was equal to $9 \mathrm{~m}$. The height of the transversal arch and the amount of the arch's segments changed from 1.29 to $3 \mathrm{~m}$ and from 5 to 10 , correspondingly. The height of the transversal arch was taken in such a way, that the relation between the span of considered framework and the height of the transversal arch changed from 3 to 7 . The spacing of transversal arches changed from 0,7 to $2,1 \mathrm{~m}$.

The load-bearing framework of spacious exterior structure was analyzed by the FEM, realized by the program Axis VM 12 at the action of the dead weight and uniformly distributed snow load. Design values of the dead weight and snow loads were equal to 0,66 and $1,35 \mathrm{kPa}$, correspondingly. The dead weight of the structure consisted of the dead weight of aluminium profiles and glass [18]. The snow load was determined for Riga climatic conditions [19]. The following parameters were taken for the considered grades of aluminium alloys [3]: modulus of elasticity $7000 \mathrm{kN} / \mathrm{cm}^{2}$, Poisson's ratio 0,32 and density $2700 \mathrm{~kg} / \mathrm{m}^{3}$.

The separate structural block, shown in Figure 8, was considered for evaluation of rational parameters of the whole framework. Comparison of the internal forces was conducted for the separate structural block and for the whole load-bearing framework for the variant with the height of the transversal arch and the amount of the arch's segments equal to $3 \mathrm{~m}$ and 10, correspondingly. The difference between the obtained results does not exceed $20 \%$. It enables us to make a conclusion, that the separate structural block can be considered for evaluation of rational parameters of the whole framework. It enables to decrease considerably the workability of the numerical experiment because the total amount of considered variants of the framework was equal to 27 for each of three considered grades of aluminium alloys. The values of coefficients of second power polynomial equations of the main geometrical parameters of the load-bearing framework of spacious exterior structure are given in Table 1. The coefficients were determined by the computer program EdaOpt [20].

Table 1. The coefficients of second power polynomial equations

\begin{tabular}{|c|c|c|c|}
\hline $\begin{array}{c}\text { Coefficients of second power } \\
\text { polynomial equations }\end{array}$ & $\begin{array}{c}\text { Aluminium alloy of } \\
\text { grade EN-AW-5454 }\end{array}$ & $\begin{array}{c}\text { Aluminium alloy of } \\
\text { grade EN-AW-6060 T66 }\end{array}$ & $\begin{array}{c}\text { Aluminium alloy of } \\
\text { grade EN-AW-7020 T6 }\end{array}$ \\
\hline$b_{0}$ & 21.06 & 19.78 & 20.04 \\
\hline$b_{1}$ & -5.90 & -5.49 & -5.59 \\
\hline$b_{2}$ & -3.42 & -3.17 & -3.09 \\
\hline$b_{3}$ & -1.52 & -1.50 & -1.57 \\
\hline$b_{11}$ & 1.82 & 1.61 & 1.57 \\
\hline$b_{12}$ & -0.33 & -0.23 & -0.17 \\
\hline$b_{13}$ & -0.03 & -0.04 & -0.04 \\
\hline$b_{22}$ & 1.24 & 1.09 & 1.02 \\
\hline$b_{23}$ & 0.26 & 0.21 & 0.20 \\
\hline$b_{33}$ & 0.06 & 0.06 & 0.07 \\
\hline
\end{tabular}

Let us consider a graphical view of the obtained dependences. The dependences of the materials consumption on the height and spacing of the transversal arch obtained for the aluminium alloy of grade EN-AW-6060 T66 and EN-AW-7020 T6 are given in Figure 9.

Hirkovskis A., Serdjuks D., Goremikins V., Pakrastins L., Vatin N.I. Behaviour analysis of load-bearing aluminium members 
a)

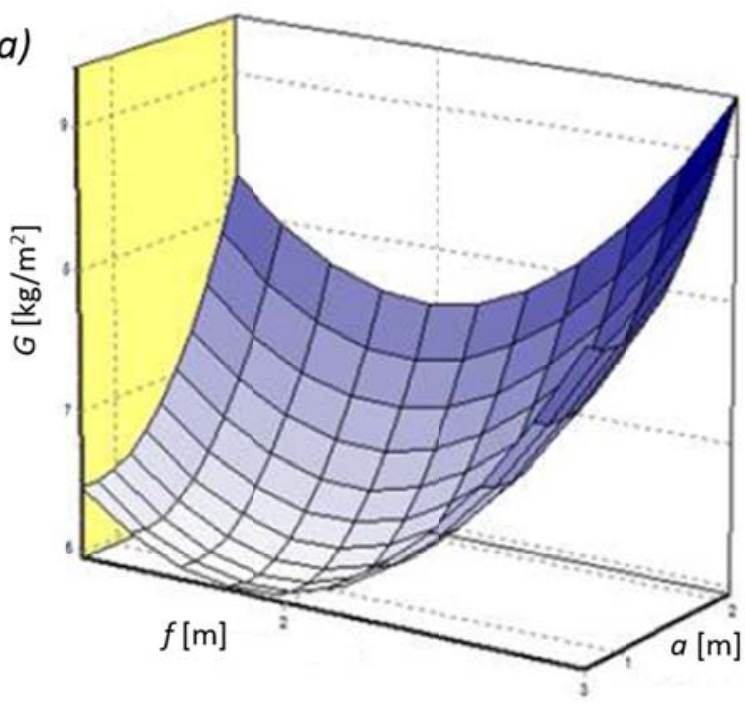

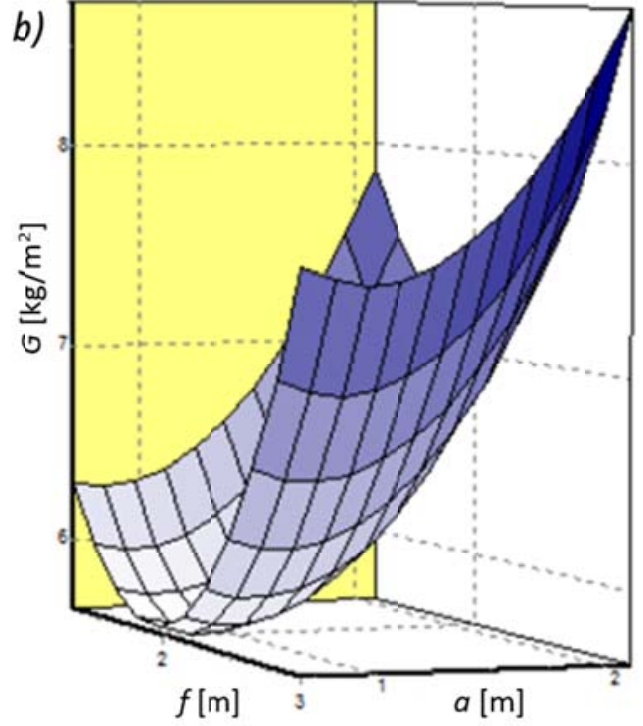

Figure 9. The materials consumption as a function of the height and spacing of the transversal arch: a) for the aluminium alloy of grade EN-AW-6060 T66;

b) for the aluminium alloy of grade EN-AW-7020 T6

The dependences of the materials consumption on the height of the transversal arch and the amount of the arch's segments obtained for the aluminium alloy of grade EN-AW-6060 T66 and EN-AW-7020 T6 are given in Figure 10.
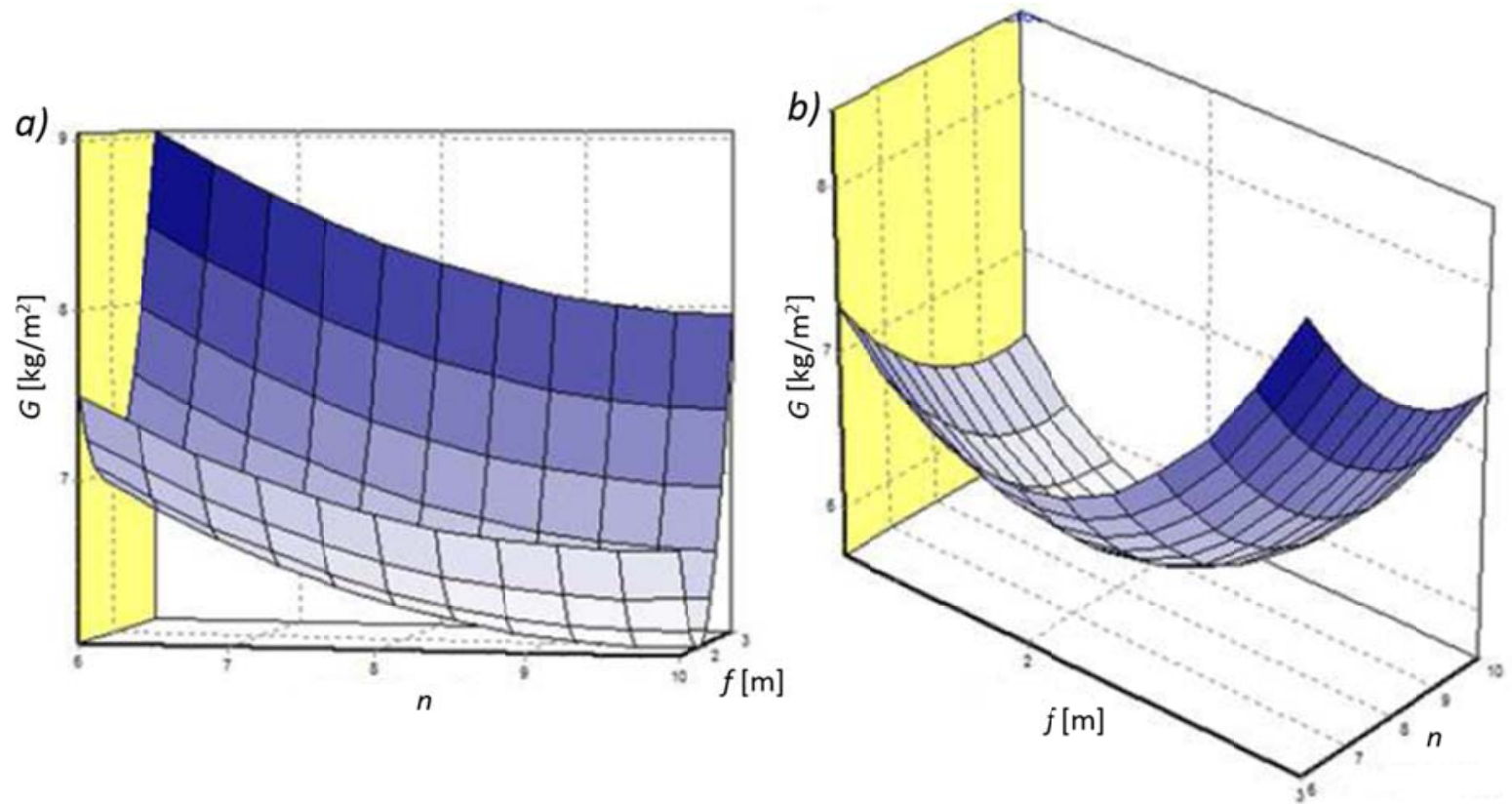

Figure 10. The materials consumption as a function of the height of the transversal arch and the amount of the arch's segments: a) for the aluminium alloy of grade EN-AW-6060 T66; b) for the aluminium alloy of grade EN-AW-7020 T6

The obtained dependences indicate that the materials consumption changes from 5,14 to $11,50 \mathrm{~kg} / \mathrm{m}^{2}$ while the height of the transversal arch and the amount of the arch's segments change from 1,29 to $3 \mathrm{~m}$ and from 5 to 10 , correspondingly. At the same time, the spacing of transversal arches changes from 0,7 to $2,1 \mathrm{~m}$.

The rational height of the transversal arch, the amount of the arch's segments and the spacing of the transversal arches were determined by the systems of equations, which were obtained by taking the partial derivatives from each parameter and making them equal to zero.

Hirkovskis A., Serdjuks D., Goremikins V., Pakrastins L., Vatin N.I. Behaviour analysis of load-bearing aluminium members 


$$
\left\{\begin{array}{l}
\frac{\partial G}{\partial f}=b_{1}+b_{12} \cdot n+b_{13} \cdot a+2 \cdot \mathrm{b}_{11} \cdot f=0 \\
\frac{\partial G}{\partial n}=b_{2}+b_{12} \cdot f+b_{23} \cdot a+2 \cdot b_{22} \cdot n=0 \\
\frac{\partial G}{\partial a}=b_{3}+b_{13} \cdot f+b_{23} \cdot n+2 \cdot b_{33} \cdot a=0
\end{array}\right.
$$

The values of the height of the transversal arch, the amount of the arch's segments and the spacing of the transversal arches were obtained by the system of equations (12), and then was corrected by the inspection. It was shown, that the rational spacing of transversal arches changed from 0,37 to $0,67 \mathrm{~m}$ for the aluminium alloys of grades EN-AW-5454, EN-AW-6060 T66 and EN-AW-7020 T6. It was also shown, that the rational height of the transversal arch and thr amount of the arch's segments changed from $1,76 \mathrm{~m}$ to $1,94 \mathrm{~m}$ and from $10,70 \mathrm{~m}$ to $11,97 \mathrm{~m}$, correspondingly. The corresponding minimum materials consumptions were equal to $6,16,5,38$ and $5,54 \mathrm{~kg} / \mathrm{m}^{2}$ for the aluminium alloys of grades EN-AW-5454, EN-AW-6060 T66 and EN-AW-7020 T6, correspondingly.

\section{Conclusions}

The design approaches described in EN 1999 and SNiP 2.03.06-85 for the aluminium elements, subjected to bending and combined bending and compression were compared analytically and experimentally for the simple beams with the rectangular hollow cross-sections with the heights of $65 \mathrm{~mm}, 85 \mathrm{~mm}$ and $105 \mathrm{~mm}$ loaded by the two concentrated forces with the load intensity from 2 to $12 \mathrm{kN}$. It was stated, that the difference between the results obtained out of EN 1999 and SNiP 2.03.0685 was within the limits from $5.82 \%$ to $12.92 \%$. The differences between the experimental and numerical results are within the limits from $3 \%$ to $7 \%$ for both methods.

Rational values of the height of the transversal arch, the amount of the arch's segments and the spacing of the transversal arches of load-bearing framework for spacious exterior structure were determined by the response surface method. The span of the considered framework was equal to $9 \mathrm{~m}$. The height of the transversal arch and the amount of the arch's segments changed from 1,29 to $3 \mathrm{~m}$ and from 5 to 10, correspondingly. The spacing of transversal arches changed from 0,7 to $2,1 \mathrm{~m}$. The dependences between the height of transversal arch, the amount of the arch's segments, the spacing of transversal arches and the materials consumption were obtained for the framework made of the aluminium alloys of grades EN-AW-5454, EN-AW-6060 T66 and EN-AW-7020 T6. It was shown, that the rational height of the transversal arch and the amount of the arch's segments changes from $1,76 \mathrm{~m}$ to $1,94 \mathrm{~m}$ and from 10,70 to 11,97 , correspondingly. The corresponding minimum materials consumptions were equal to $6,16,5,38$ and $5,54 \mathrm{~kg} / \mathrm{m}^{2}$.

The research leading to these results has received the funding from Latvia state research program under the grant agreement "Innovative Materials and Smart Technologies for Environmental Safety, IMATEH". Project Nr.3, PVS ID1854, Task Nr.3.

\section{References}

1. EN1999-1-1. Eurocode 9: Design of aluminium structures. Part 1-1: General structural rules. Brussels: European Committee for Standartisation, 2007. 209 p.

2. SNiP 2.03.06-85. Alyuminiyevyye konstruktsii [Russian building codes 2.03.06-85. Aluminum structures]. Moscow: GOSSTROY SSSR, 1986. 48 p. (rus)

3. Polmear I.J. Light Alloys. Arnold, 1995. 362 p.

4. Artemyeva I. N. Alyuminiyevyye konstruktsii [Aluminum structures]. Leningrad: Stroyizdat, 1976. 204 p. (rus)

5. Goremikins V. Rational Large Span Prestressed Cable Structure. Doctoral Thesis. Riga: RTU, 2013. $155 \mathrm{p}$.

6. Bonet J., Wood R.D., Mahaney J., Heywood P. Finite element analysis of air supported membrane structures. Computer Methods in Applied Mechanics and Engineering. 2000. No. 190. Pp. 579-595.

Hirkovskis A., Serdjuks D., Goremikins V., Pakrastins L., Vatin N.I. Behaviour analysis of load-bearing aluminium members 
7. Xianzhong Z., Yiyi C., Zuyan S., Yangji C., Dasui W., Jian Z. Prestressing and Loading Tests on FullScale Roof Truss of Shanghai Pudong International Airport Terminal. In Proc. of the Second International Conference on Advances in Steel Structures, 15-17 December, 1999, Hong Kong, China. 1999. Pp. 731-738.

8. Kikot A.A., Grigoriev V.V. Vliyaniye shiriny poyasa i parametrov stenki na effektivnost stalnogo tonkostennogo kholodnognutogo profilya Sigma-obraznogo secheniya pri rabote na izgib [Influence of Flange Width and Wall Parameters on Effectiveness of Cold-Formed Steel Sigma-Profile in Bending Behaviour]. Magazine of Civil Engineering. 2013. No. 1(360. Pp. 97-102. (rus)

9. Pakrastinsh L., Rocens K., Serdjuks D. Deformability of Hierarchic Cable Roof. Journal of Constructional Steel Research. 2006. No. 62. Pp. 1295-1301.

10. Goremikins V., Rocens K., Serdjuks D. Cable Truss Analyses for Suspension Bridge. In Proc. of 10th International Scientific Conference "Engineering for Rural Development", 24-25 May, 2012, Jelgava, Latvia. 2012. Pp. 228-233.

11. Chen W.F., Lui E.M. Handbook of structural engineering. Boca Raton: CRC Press, 2005. 625 p.

12. Cai J., Feng J., Jiang C. Development and analysis of a long-span retractable roof structure. Journal of Constructional Steel Research. 2014. No. 92. Pp. 175-182.

13. Goremikins V., Rocens K., Serdjuks D. Decreasing Displacements of Prestressed Suspension Bridge. Journal of Civil Engineering and Management. 2012. No. 18(6). Pp. 858-866.

14. Semenov A.A., Porivajev I.A., Safiullin M.N. Issledovaniya vetrovoy i snegovoy nagruzok na pokrytiya vertikalnykh tsilindricheskikh rezervuarov [Research of Wind and Snow cover loads on the Roofs of the Vertical Cylindrical Tanks]. Magazine of Civil Engineering. 2012. No. 5(31). Pp. 12-22. (rus)

15. Lisicins M., Mironovs V. Analysis of Perforated Steel Tape Usage Possibility in Construction. In Proc. of 3rd International Scientific Conference "Civil Engineering' 11", 2011, Jelgava, Latvia. 2011. Pp. 95-102.

16. Goremikins V., Rocens K., Serdjuks D. Decreasing of Displacements of Prestressed Cable Truss. World Academy of Science, Engineering and Technology. 2012. No. 63. Pp. 554-562.

17. Goremikins V., Rocens K., Serdjuks D., Pakrastins L., Vatin N. Decreasing of Displacements of Prestressed Cable Truss. Advances in Civil Engineering and Building Materials. 2015. No. 4. Pp. 363-367.

18. EN1991-1-1. Eurocode 1: Action on structures. Part 1-1: General actions - Densities, self-weight and imposed loads for buildings. Brussels: European Committee for Standartisation, 2003. 47 p.

19. EN1991-1-3. Eurocode 1: Action on structures. Part 1-3: General actions - Snow loads. Brussels: European Committee for Standartisation, 2003. 59 p.

20. Auzukalns J. Manual of software EdaOpt. Riga: RTU, 2007.

Arturs Hirkovskis, Riga, Latvia +37112345678; e-mail: arturs.hirkovskis@rtu.Iv

Dmitrijs Serdjuks, Riga, Latvia +37126353082; e-mail: Dmitrijs.Serdjuks@rtu.Iv

Vadims Goremikins, Riga, Latvia +37129231772; e-mail: goremikins@gmail.com

Leonids Pakrastins, Riga, Latvia +37129452138; e-mail: leonids.pakrastins@rtu.Iv

Nikolai I. Vatin, St. Petersburg, Russia +79219643762; e-mail: vatin@mail.ru

(C) Hirkovskis A., Serdjuks D., Goremikins V., Pakrastins L., Vatin N.I.

Hirkovskis A., Serdjuks D., Goremikins V., Pakrastins L., Vatin N.I. Behaviour analysis of load-bearing aluminium members 


\title{
Анализ работы несущих элементов из алюминиевых сплавов
}

\author{
M.Sc., Студент А. Хирковский; \\ д-р техн. наук, профессор Д.О. Сердюк; \\ д-р техн. наук, ведущий научный сотрудник В.В. Горемыкин; \\ д-р техн. наук, заведующий кафедрой Л. Пакрастиньш, \\ Рижский технический университет \\ д-р техн. наук, директор Инженерно-строительного института Н.И. Ватин, \\ Санкт-Петербургский политехнический университет Петра Великого
}

\section{Ключевые слова}

рациональные параметры; пространственная алюминиевая конструкция; метод поверхности отклика

\section{Аннотация}

Алюминий является одним из традиционных конструктивных материалов. Среди основных преимуществ его сплавов выделяются повышенная стойкость к коррозии, устойчивость механических свойств при отрицательных температурах, легкость и высокая прочность. Конструкции, изготовленные из алюминиевых сплавов, широко используются в строительстве для возведения новых гражданских и промышленных зданий, а также для реконструкции существующих.

Методы расчета, описанные в Еврокоде 9 и СНиП 2.03.06-85 для элементов из алюминиевых сплавов, подвергнутых изгибу и сжатию с изгибом, сравнивались аналитически между собой, а также с результатами лабораторного эксперимента для простой балки с прямоугольным трубным сечением и высотой сечения 65 мм, 85 мм и 105 мм, загруженной двумя сосредоточенными силами. Показано, что разница между результатами расчета по двум методам находится в пределах от 5,82 \% до 12,92 \%. Различия между экспериментальными и численными результатами находятся в пределах от $3 \%$ до 7 \% для обоих методов.

Рациональные значения высоты поперечной арки, количество ее сегментов и шаг поперечных арок несущего каркаса для пространственной конструкции были определены методом поверхности отклика для структуры с пролетом, равным 9 м. Было показано, что рациональные значения высоты поперечной арки и количества сегментов изменяются в пределах от 1,76 м до 1.94 м и от 10,70 до 11,97 соответственно. Минимальный расход материала равен 6,16, 5,38 и $5,54 \mathrm{\kappa} / \mathrm{M}^{2}$.

\section{Лumepamypa}

1. EN1999-1-1. Eurocode 9: Design of aluminium structures. Part 1-1: General structural rules. Brussels: European Committee for Standartisation, 2007. 209 p.

2. СНиП 2.03.06-85. Алюминиевые конструкции. М.: ГОССТРОЙ СССР, 1986. 48 с.

3. Polmear I.J. Light Alloys. Arnold, 1995. 362 p.

4. Артемьева И. Н. Алюминиевые конструкции. Л.:Стройиздат, 1976. 204 с.

5. Goremikins V. Rational Large Span Prestressed Cable Structure. Doctoral Thesis. Riga: RTU, 2013. $155 \mathrm{p}$.

6. Bonet J., Wood R.D., Mahaney J., Heywood P. Finite element analysis of air supported membrane structures // Computer Methods in Applied Mechanics and Engineering. 2000. №190. Pp. 579-595.

7. Xianzhong Z., Yiyi C., Zuyan S., Yangji C., Dasui W., Jian Z. Prestressing and Loading Tests on FullScale Roof Truss of Shanghai Pudong International Airport Terminal // Proc. of the Second International Conference on Advances in Steel Structures, 15-17 December, 1999, Hong Kong, China. 1999. Pp. 731-738.

8. Киков А.А., Григорьев В.В. Влияние ширины пояса и параметров стенки на эффеективность стального тонкостенного холодногнутого профиля Сигма-образного сечения при работе на изгиб // Инженерно-строительный журнал. 2013. №36. С. 97-102.

9. Pakrastinsh L., Rocens K., Serdjuks D. Deformability of Hierarchic Cable Roof // Journal of Constructional Steel Research, 2006. № 62. Pp. 1295-1301.

Хирковский А., Сердюк Д.О., Горемыкин В.В., Пакрастиньш Л., Ватин Н.И. Анализ работы несущих элементов из алюминиевых сплавов 
10. Goremikins V., Rocens K., Serdjuks D. Cable Truss Analyses for Suspension Bridge // In Proc. of 10th International Scientific Conference "Engineering for Rural Development", 24-25 May, 2012, Jelgava, Latvia. 2012. Pp. 228-233.

11. Chen W.F., Lui E.M. Handbook of structural engineering. Boca Raton: CRC Press, 2005. 625 p.

12. Cai J., Feng J., Jiang C. Development and analysis of a long-span retractable roof structure // Journal of Constructional Steel Research. 2014. № 92. Pp. 175-182.

13. Goremikins V., Rocens K., Serdjuks D. Decreasing Displacements of Prestressed Suspension Bridge // Journal of Civil Engineering and Management. 2012. №18(6). Pp. 858-866.

14. Порываев И.А., Сафиуллин М.Н., Семенов А.А. Исследования ветровой и снеговой нагрузок на покрытия вертикальных цилиндрических резервуаров // Инженерно-строительный журнал. 2012. №5(31). C. 12-22.

15. Lisicins M., Mironovs V. Analysis of Perforated Steel Tape Usage Possibility in Construction // In Proc. of 3rd International Scientific Conference "Civil Engineering' 11", 2011, Jelgava, Latvia. 2011. Pp. 95-102.

16. Goremikins V., Rocens K., Serdjuks D. Decreasing of Displacements of Prestressed Cable Truss // World Academy of Science, Engineering and Technology. 2012. № 63. Pp. 554-562.

17. Goremikins V., Rocens K., Serdjuks D., Pakrastins L., Vatin N. Decreasing of Displacements of Prestressed Cable Truss // Advances in Civil Engineering and Building Materials. 2015. №4. Pp. 363-367.

18. EN1991-1-1. Eurocode 1: Action on structures. Part 1-1: General actions - Densities, self-weight and imposed loads for buildings. Brussels: European Committee for Standartisation, 2003. 47 p.

19. EN1991-1-3. Eurocode 1: Action on structures. Part 1-3: General actions - Snow loads. Brussels: European Committee for Standartisation, 2003. 59 p.

20. Auzukalns J. Manual of software EdaOpt. Riga: RTU, 2007.

Полный текст статьи на английском языке: с. 86-96

Хирковский А., Сердюк Д.О., Горемыкин В.В., Пакрастиньш Л., Ватин Н.И. Анализ работы несущих элементов из алюминиевых сплавов 